This is the author's version of

Blanca Ramírez Barat, Ana Crespo, Emma García, Soledad Díaz, Emilio Cano, "An EIS study of the conservation treatment of the bronze sphinxes at the Museo Arqueológico Nacional (Madrid)" Journal of Cultural Heritage, volume 24, 2017, Pages 93-99.

https://doi.org/10.1016/i.culher.2016.10.010. 


\title{
AN EIS STUDY OF THE CONSERVATION TREATMENT OF THE BRONZE SPHINXES AT THE MUSEO ARQUEOLÓGICO NACIONAL (MADRID)
}

\author{
Blanca Ramírez Barat ${ }^{1 *}$, Ana Crespo ${ }^{1}$, Emma García², Soledad Díaz ${ }^{2}$, Emilio Cano ${ }^{1}$ \\ ${ }^{1}$ Centro Nacional de Investigaciones Metalúrgicas (CENIM), Consejo Superior de \\ Investigaciones Científicas (CSIC), Av. Gregorio del Amo 8, 28040 Madrid (Spain) \\ ${ }^{2}$ Instituto del Patrimonio Cultural de España (IPCE), Ministerio de Educación, Cultura y Deporte \\ (MECD). Pintor el Greco 4, Ciudad Universitaria, 28040 Madrid (Spain) \\ * Corresponding author: blanca.ramirez@csic.es
}

\section{Abstract (500 words)}

In any conservation project, conservators have to address several questions to design the appropriate intervention strategy. Among them, the effectiveness and duration of protective treatments is an important issue, not easy to evaluate. In the field of metallic cultural heritage, electrochemical techniques such as electrochemical impedance spectroscopy (EIS) can be used to evaluate patinas and protective coatings performance. Widely used in industrial applications, the use of these techniques in conservation science is much more recent and limited.

During the restauration process of the bronze sphinxes at the main façade of the National Archaeological Museum in Madrid, collaboration with conservators has been established to test the performance of a recently developed gel-electrolyte cell for the electrochemical evaluation of metal cultural heritage. Electrochemical measurements (EIS and Rp) of the patinas have been carried out before, during and after the conservation treatments, on two different areas of the sculpture. This has provided information on how the protective coatings have improved corrosion resistance by 3 orders of magnitude, and how this protection is starting to decrease with time; periodic measurements will allow verifying the performance of the treatment over time and detecting the failure of the protection treatment before its effects are visible on the surface.

\section{Keywords (5-10):}

Conservation, outdoor sculpture, bronze, Electrochemical Impedance Spectroscopy, protective coatings, diagnostic tools

\section{Research aims (200 words)}

The objective of this work is to test and validate on a real situation a recently developed agar gel-polymer electrolyte (G-PE) cell specifically designed for in-situ electrochemical measurements on metallic cultural heritage. These measurements allow quantifying the corrosion resistance of the patina in different areas and to assess the increase in the corrosion resistance of the metal provided by the coatings and other conservation treatments. With this development we would like to provide metal conservators with a useful diagnostic tool that allows corrosion resistance evaluation of patinas and coatings, its evolution over time and to predict the failure of the protective coatings before active corrosion starts again. 


\section{Introduction}

The main façade of the National Archaeological Museum in Madrid is decorated by two bronze sphinxes, half woman, and half lioness, placed at both sides of the main staircase over a stone base. The sphinxes were designed inspired by the classical cannons by the Spanish sculptor Felipe Moratilla y Parreto, and lost-wax casted in the Madrilenian foundry Arias, in 1894. Due to their large dimensions (1.91 m. high, $3.52 \mathrm{~m}$. depth and $1.06 \mathrm{~m}$. width, and around $3.000 \mathrm{~kg}$ ) they were done in several pieces and joined together.

The sphinxes have remained in the same place -with a small displacement in 1970 due to the extension of the staircase- since the inauguration of the museum on July the 5th, 1895. During 2014, following the complete refurbishment of the Museum, all sculptures in the main façade, including the sphinxes have been restored under the supervision of the Instituto del Patrimonio Cultural de España (IPCE) [1].

In any conservation project, conservators have to address several questions to design the appropriate intervention strategy. Among them, the effectiveness and duration of protective treatments is an important issue, not easy to assess. Fortunately, for metallic objects, electrochemical techniques can provide some answers to this problem. Among these techniques, Electrochemical Impedance Spectroscopy (EIS) is a very wellestablished method to assess the anti-corrosive efficiency of protective coatings and inhibitors. However, EIS is less widespread for the study of patinas and coatings in the field of cultural heritage [2-6]. EIS is based on the application of a low-amplitude (usually $10 \mathrm{mV}$ ) alternating current (AC) voltage signal to the metallic sample using a conventional three electrode (working, i.e. the metal under study, reference and counter electrode) electrochemical cell. Measuring the $A C$ current response of the system, the impedance is calculated at different frequencies. The impedance spectra profile provides information on the corrosion and other electroactive processes taking place on a metal surface. EIS can be used to quantify the effectiveness of a conservation treatment in terms of corrosion resistance gain and repetitive measurements over time allow monitoring the decrease in protection ability of these treatments, detecting failure before it is too late. Unfortunately, application of this and other electrochemical techniques in the field of cultural heritage is not always easy, especially for insitu measurements as they usually imply the use of a liquid electrolyte in contact with the surface under study -which is not easy to handle-. On the other hand, the interpretation of results is usually hard work, as the irregularity and complexity of the surfaces and interferences from the environment do not always allow obtaining good quality spectra.

Since the mid 90's conservation scientists have started to use this technique in the evaluation of protective coatings for metallic cultural heritage [7-11], and in the last three decades several researchers have been working in the development of specific methodologies and portable devices to its application in the in-situ evaluation of patina and coatings on outdoor sculpture and monuments [12-18]. Concurrently with the restoration process of the sphinxes and within the framework of CREMEL project (Conservation-REstoration of Metal cultural heritage with ELectrochemical techniques) authors have been working in an agar gel-polymer electrolyte (G$\mathrm{PE}$ ) cell specifically designed for in-situ measurements on cultural heritage overcoming some 
of the limitations of previous designs $[19,20]$. This cell had already been successfully tested in the evaluation of protective coatings on bronze coupons [21], but it has not yet been applied in a systematic way on a real conservation problem. Now it was a good opportunity both to test the performance of the cell on a real situation and to evaluate the effectiveness of the applied treatments on the sphinxes. The complete treatment has been published in the museum's technical bulletin [1]: The internal structure has been reinforced, and after a cleaning process, $2 \%$ benzotriazole in a water-alcohol mixture was applied, followed by three layers of Incralac. In the first layer the product was used in a $15 \%$ solution in xylene, in the second layer concentration was increased to $20 \%$ in same solvent. Then, a third layer of $30 \%$ Incralac in acetone was applied followed by $10 \%$ microcrystalline wax (Cosmolloid $80 \mathrm{H}$ ) in white spirit.

Electrochemical measurements were performed using the G-PE cell on the left sphinx before, during and after the restauration process. Figure 1 shows the left sphinx during measurements before and after restoration. Measurements before restauration allowed evaluating the corrosion resistance of different areas of the sphinx. During the restoration process they gave information of the additional resistance provided by protective coatings and supported the decision on the number of layers to apply. Finally, after the restoration, periodical measurements are being done to follow the evolution of coatings over time. The objective is to detect the coating failure, i.e. the drop of resistance to initial levels, before the sculpture can be affected.
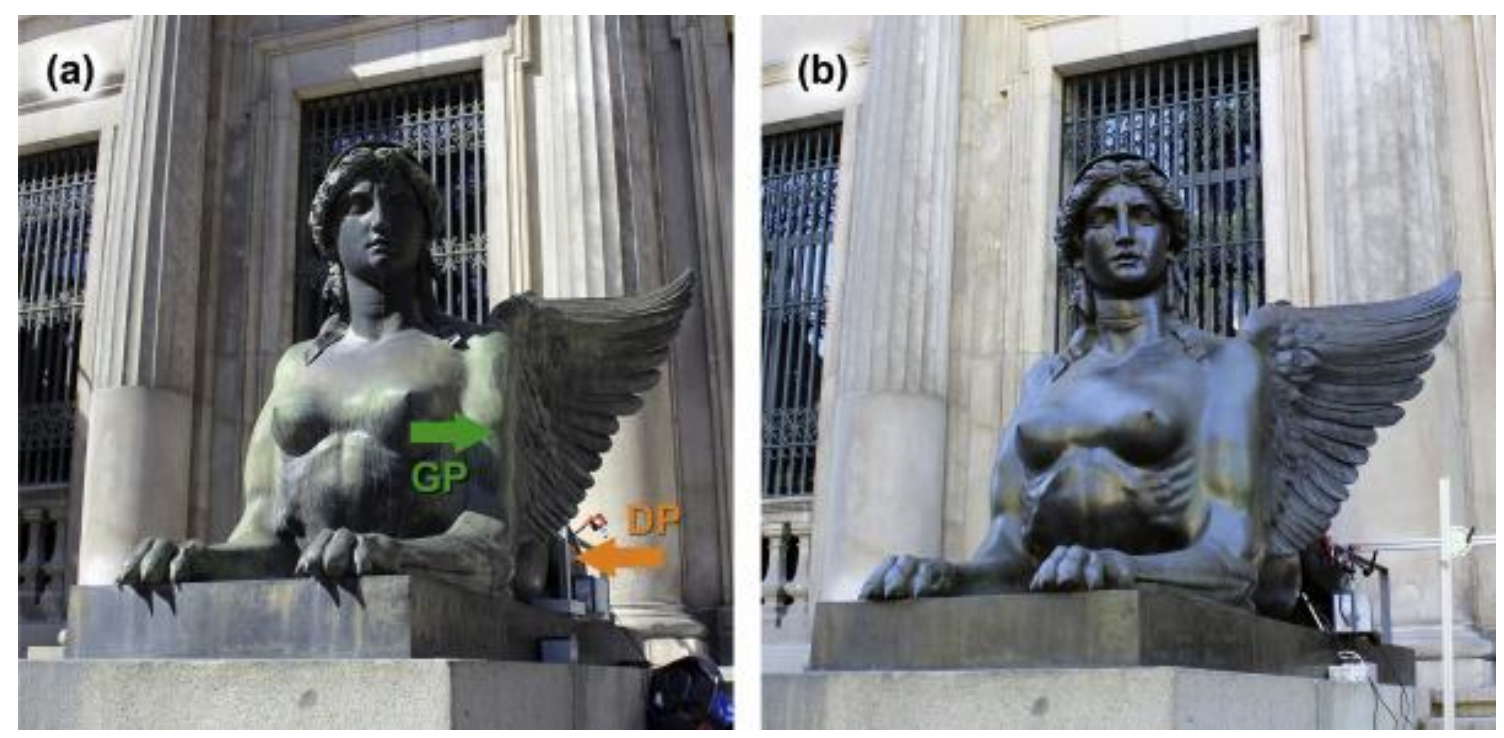

Fig. 1. Left sphinx during measurements before restoration (a) and after restoration (b). Arrows indicate the green patina (GP) and dark patina (DP) test areas.

\section{Materials and methods}

Several electrochemical impedance spectroscopy (EIS) and polarization resistance (Rp) measurements were carried out on two different areas of the southern sphinx: a greenish patina (GP) on the left arm of the sphinx and a dark patina (DP) on the left thigh of the sphinx (fig. 1). These areas have been selected as representatives of two extreme conditions of the 
surface: GP is a thick, matt patina formed in areas exposed to atmospheric corrosion; and DP is a thin, semi-transparent patina remaining from the original artificial patination treatment.

Measurements have been performed with the gel polymer electrolyte (G-PE) cell previously developed by the authors $[19,20]$. It consists of a plastic mold in which the counter electrode (CE) and a pseudo-reference electrode (RE) are attached. The CE is made with a stainless steel mesh to maximize its surface, and the RE is a $99,9 \%$ silver wire electrochemically coated with $\mathrm{AgCl}$ [22]. The mold is then filled with a traditional aqueous electrolyte that has been gelled by addition of $4 \% \mathrm{w} / \mathrm{v}$ of agar powder.

The liquid electrolyte in which agar is dissolved to obtain the gel electrolyte is synthetic rain adapted from Bernardi [23]. It contains $14.43 \mathrm{mg} / \mathrm{L} \mathrm{CaSO}_{4} \cdot 2 \mathrm{H}_{2} \mathrm{O}, 15.04 \mathrm{mg} / \mathrm{L}\left(\mathrm{NH}_{4}\right) 2 \mathrm{SO}_{4}, 19.15$ $\mathrm{mg} / \mathrm{L}\left(\mathrm{NH}_{4}\right) \mathrm{Cl}, 15.13 \mathrm{NaNO}_{3}$ and $3.19 \mathrm{mg} / \mathrm{L} \mathrm{CH}_{3} \mathrm{COONa}$, prepared in distilled water. Synthetic rain has been chosen to mimic the corrosive environment which the sculptures are exposed to, so the interaction of the electrolyte with the metal, patina and coating is similar to actual degradation process, and the object is not exposed to other ions [24]. This solution has been used 10x concentrated with a final $\mathrm{pH}$ adjusted to 6.5 with $\mathrm{HNO}_{3}$, to provide a mild electrolyte which prevents any damage to the patina, but with enough conductivity to measure. The agar powder has been dispersed in the electrolyte and heated until dissolution. After a few minutes, the liquid has been poured into the mold and left to cool until solidification. The cell is then mounted on a support with an articulated arm which allows positioning on the surface to be measured; the measurement area $5.72 \mathrm{~cm}^{2}$. A more detailed description of the cell has been provided in references $[19,20]$. Figure 2 illustrates the realization of measurements on the sculptures. A closer view of the cell placed on the surface of the sculpture during measurements can be seen in figure 2 (a), while figure 2 (b) shows the RE and CE inside the cell, and the imprint of the surface texture on the gel. Measured areas were photographed in detail to ensure that no marks were left on the surface and that subsequent measurements were done on the same point (fig. 3).
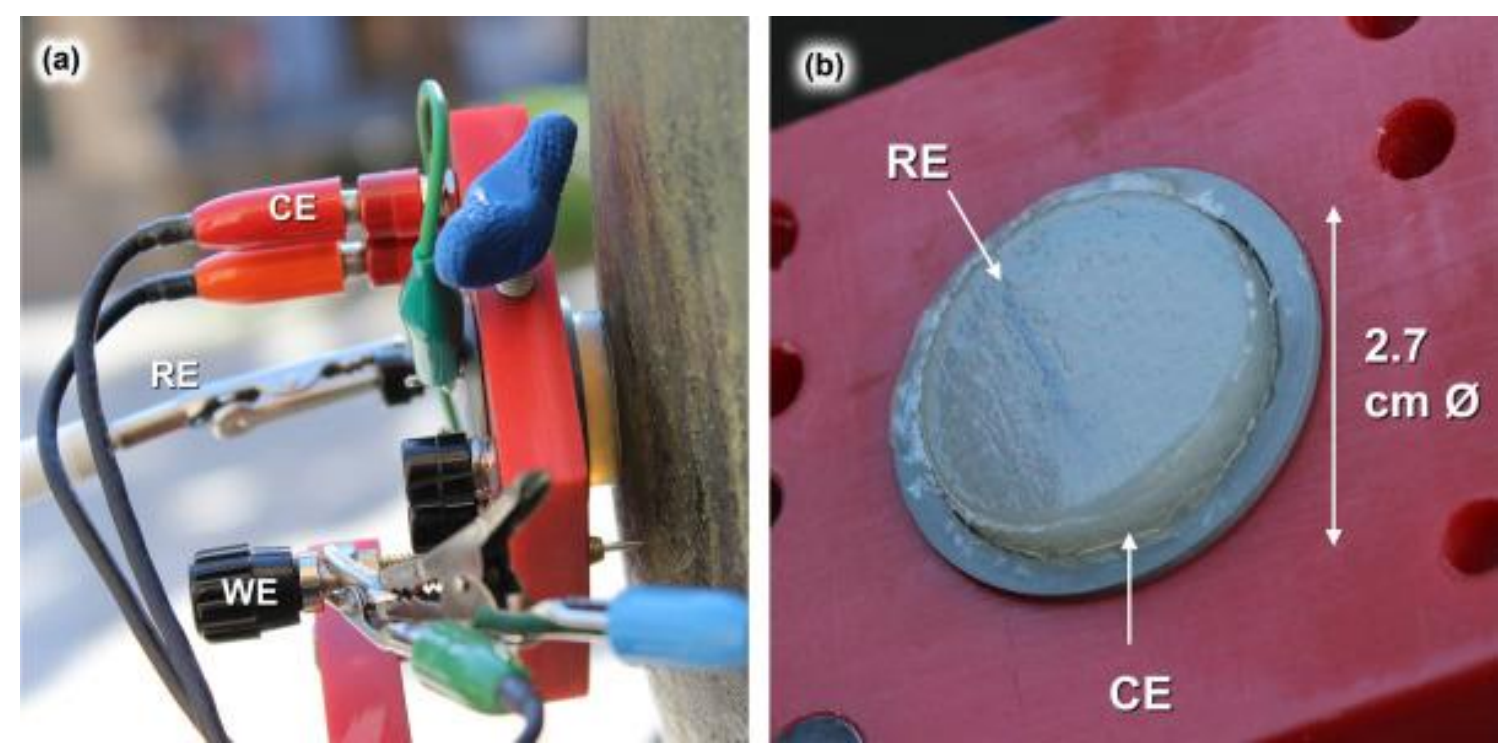

Fig. 2. Detail of the cell during measurements. It can be seen how the gel adapts to the surface of the sculpture (left) and the deformation of the cell surface after measurement (right). 

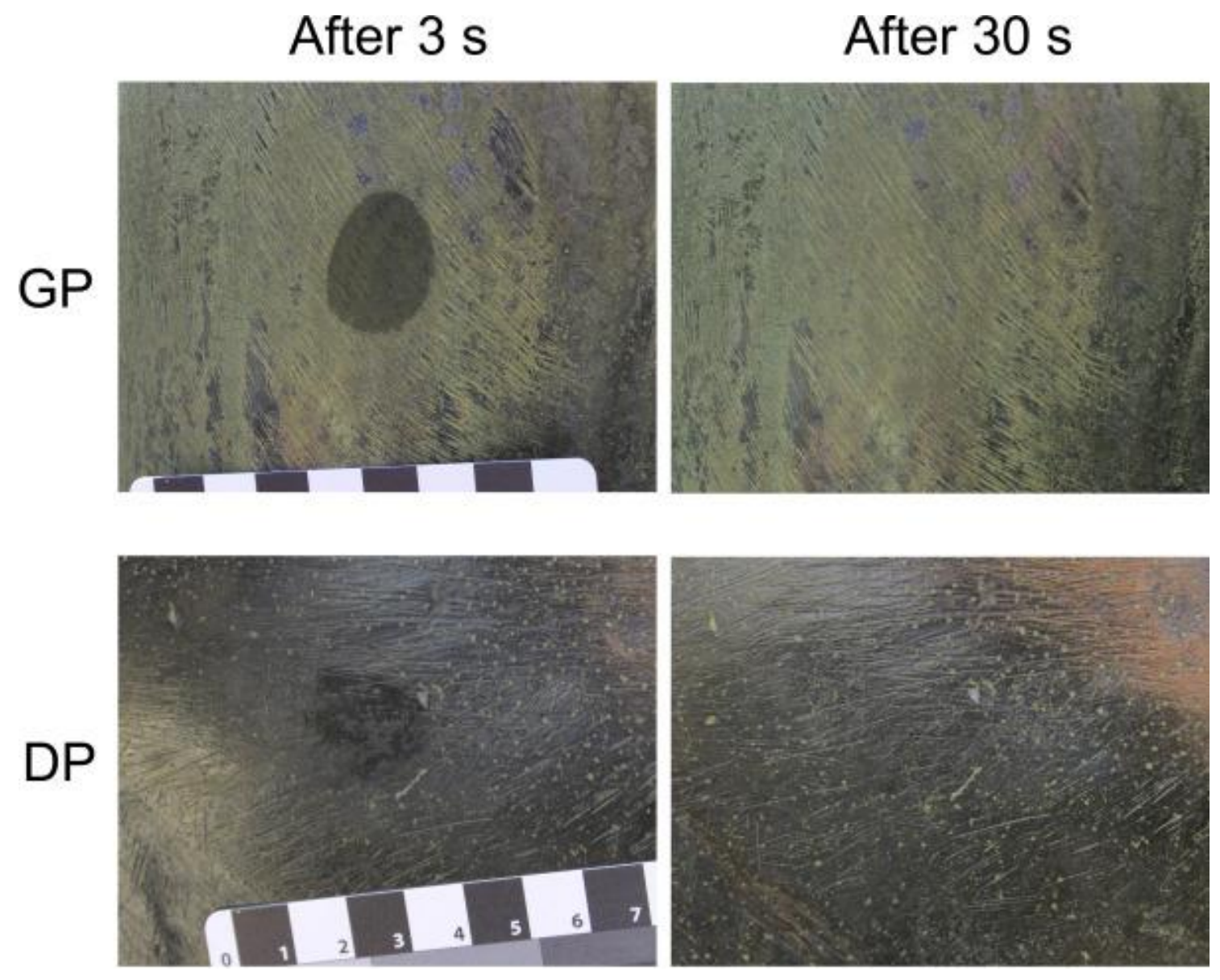

Fig. 3. Detail of the surface after measurement showing that no marks are left after it (before conservation treatment).

First data were taken in March 2014, before restoration; a second set of measurements was done in July during restoration treatment (after cleaning and first coating layer), then after restoration, in early January, May and November 2015 and in June 2016 (approximately 5, 10, 16 and 23 months later). EIS and Rp measurements were performed consecutively each patina. EIS spectra have been acquired with a Gamry 600 Potentiostat, using a frequency swept from $100 \mathrm{kHz}$ to $10 \mathrm{mHz}, 10 \mathrm{mV}$ RMS amplitude and 10 points/decade. Polarization resistance (Rp) has been measured using the same setup, performing a $0.16 \mathrm{mV} / \mathrm{s}$ swept from -10 to $+10 \mathrm{mV}$ vs. open circuit potential. All results have been normalized to the measurement area. Due to the limited access to the sphinxes, single measurements were made at each time. However, the reproducibility and repeatability of measurements using this system has been validated in a previous work by the authors [20].

\section{Results and discussion}

G-PE cell has shown to fulfil the requirements for in situ measurements, on rough, leaning and slightly curved surfaces. In figure 2 , the flexibility and adaptability of the cell to the surface under study, following the roughness of the patina, can be appreciated. The non-destructive character of the measurements has also been verified in the worst case scenario, i.e., before protection treatment. Figure 3 shows the visual appearance of the patinas just after removal of the gel-cell (left) and a few seconds later (right). It can be observed how the wetted area dries 
out immediately leaving no traces on the surface proving the non-destructive character of the technique [25]. On the long term, no visible effects have been observed after the series of measurements.

The evolution of the impedance's modulus for DP and GP is presented in figure 4. EIS spectra are rather noisy at the high frequency region. As the museum is located in the city center, surrounded by traffic, subway and train tunnels, the quality of EIS spectra may be affected by environmental interferences. Similar noisy spectra at high frequencies has also been observed by other authors in on-site EIS measurements in sculptures [17]. This effect is more important after the restoration process, as the application of a thick layer of Incralac highly reduces the intensity of the electric signal decreasing the signal to noise ratio. The noise of the EIS data does not allow an in-depth analysis of the corrosion and protection mechanisms from the electrochemical results. Despite this, the results clearly show some general features and trends that allow comparing the result in different areas and study the evolution of impedance over time.

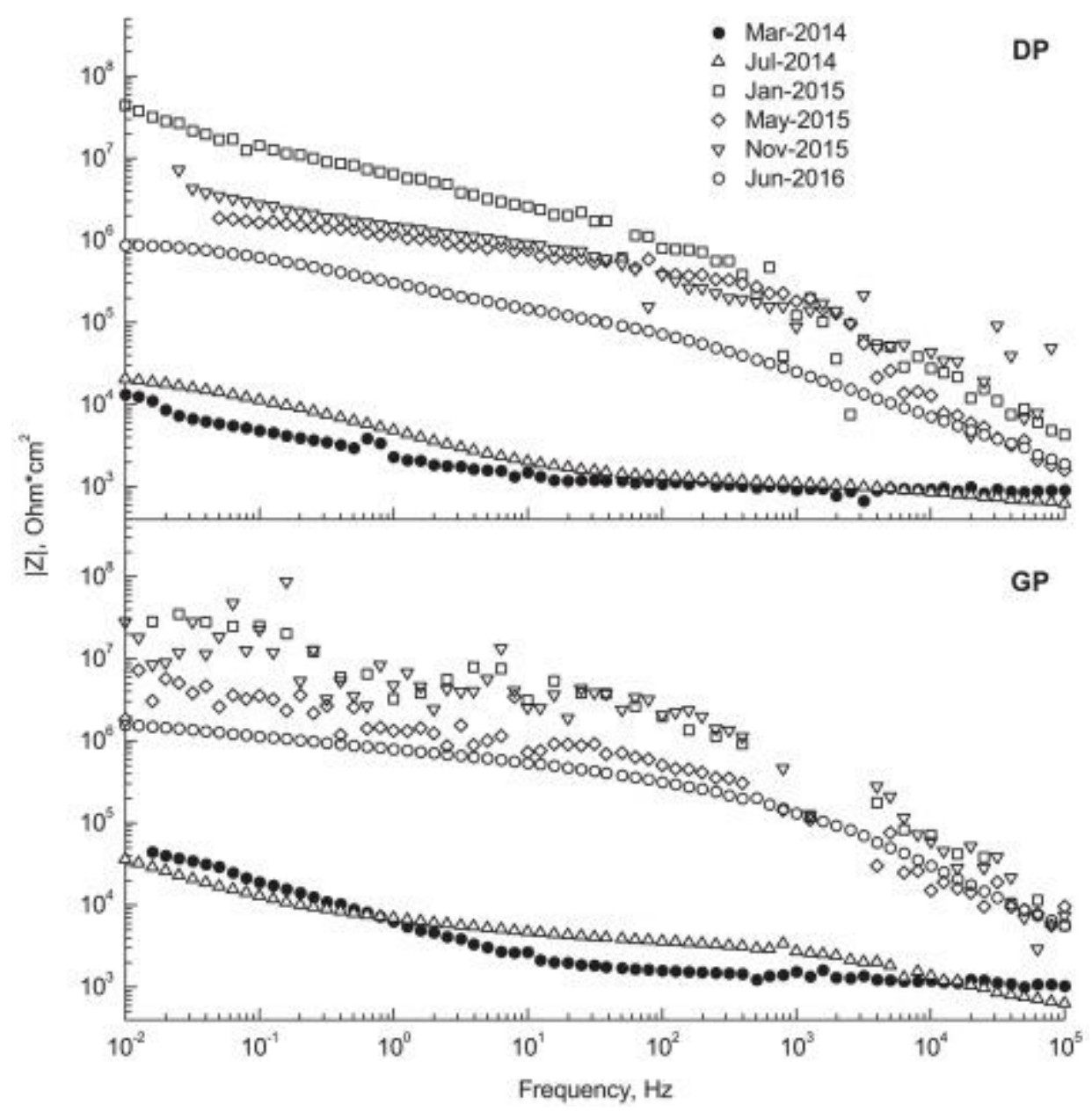

Fig. 4. Evolution of impedance modulus with time for dark patina (DP) and green patina (GP).

Impedance data are generally analyzed using equivalent circuits, in which passive electric elements such as resistors, capacitors, etc. are used to reproduce the electric characteristics of 
the system $[3,24]$. Thus, to interpret the results we need to consider the nature of our system, a bronze sculpture covered with a patina, to which an organic coating has been applied. The corrosion of the sculpture takes place when the rain (electrolyte), containing dissolved oxygen and atmospheric pollutants, reaches the base metal and the corrosion reactions take place. The anodic process involves the dissolution of the metal (copper and alloying elements) while the cathodic reaction is the reduction of dissolved oxygen. For the corrosion reaction to take place several resistances (or impedances) have to be overcome. The charged species have to travel across the electrolyte, against the electrolyte resistance, and reach the coating. Conductivity through the coating has two contributions, the charge of the capacitor at both sides of the coating and the resistance through its pores, thus the impedance of a coating is usually represented by a capacitor and a resistance in parallel. The same behavior is to be expected for the patina. Finally, when the electrolyte reaches the metal surface, the corrosion process can be assimilated to another pair capacitor-resistance in parallel, representing the capacity of the electrochemical double layer and the charge transfer resistance. This is probably the simplest approach, in which the equivalent circuit could be represented by one resistance in series with two or three nested capacitor-resistance pairs $[2,11,26,27]$. In practice, circuits can get much more complicated when other physicochemical phenomena get involved and several processes overlap [28]. In the first place, these systems do not follow the ideal capacitive behavior, and constant phase elements (CPE) have to be used instead of capacitors [3] adding new calculations to obtain capacity values from CPE parameters [29]. Also, diffusion effects may appear, requiring the introduction of other elements such as Warburg impedance and in some cases, reactivity of the patina itself require the employment of transmission lines [20,30,31]. There are several good reviews about EIS of coated metals which can be consulted for further information. [4, 32-34]

Difficulties in the interpretation of EIS spectra from cultural heritage objects are not an unknown fact. Surface inhomogeneities together with environmental interferences in field measurements lead frequently to evaluate EIS data in terms of simplified approaches [3]. Thus the value of $|Z|$ at the low frequency limit has been used as a measure of the protective effectiveness of the surface layers or the corrosion resistance and applied to comparative studies $[5,8,10,13,35-37]$. This value is the sum of the impedance of the coating plus all the other aforementioned elements (electrolyte resistance, charge transfer resistance, diffusion impedances, etc.). In the case of organic coatings, the contribution of these other elements is usually much smaller than the coating impedance, so the film resistance dominates the spectra at low frequencies. Although a deeper interpretation would be desirable, information given by this simplified approach has proven to be effective to assess the protective properties of coating systems for outdoor bronze monuments and its evolution over time [5, 37].

The variation of the impedance module, $|Z|$, at the lower frequencies for DP and GP on successive measurements, together with the $\mathrm{Rp}$ values are represented in figure 5 . Although the EIS spectra were acquired from $100 \mathrm{kHz}$ to $10 \mathrm{mHz}, 15.8 \mathrm{mHz}$ has been used as lowest frequency limit as some points are missing at the lowest frequency value. From this figure, several facts can be pointed out, supported both by $|Z|_{15.8 \mathrm{mHz}}$ and Rp results. Before restoration (March 2014) GP was about 5 times more protective than DP, while after treatments, both areas showed similar behavior. From data of July 2014 it is clearly appreciated that the first protective coating with $2 \%$ benzotriazole and $15 \%$ Incralac does not 
give an appreciable protection, as $|Z|$ has barely increased from its initial value, thus justifying the need of additional varnish layers. After the whole protection treatment has been applied, $|Z|$ has increased three orders of magnitude as can be observed in the measurement done in January 2016. Differences between DP and GP are now insignificant, indicating that the coating is the main responsible for protective properties of the system, thus being the patina contribution negligible. From this moment, the resistance of the coating begins a slow decay, although two years after application it is still offering a good protection when compared with the initial results before restoration. It also appears to be a seasonal effect that may increase resistance values in cooler months (comparing Jan. and Nov. 2015 vs. May 2015 and Jun. 2016); higher temperatures may induce higher conductivity of the aqueous solutions that penetrate into the coating and cause a progressive reduction of the impedance, as well as increase the anodic and/or cathodic corrosion reaction rates. This effect of temperature on measurements is currently under study.

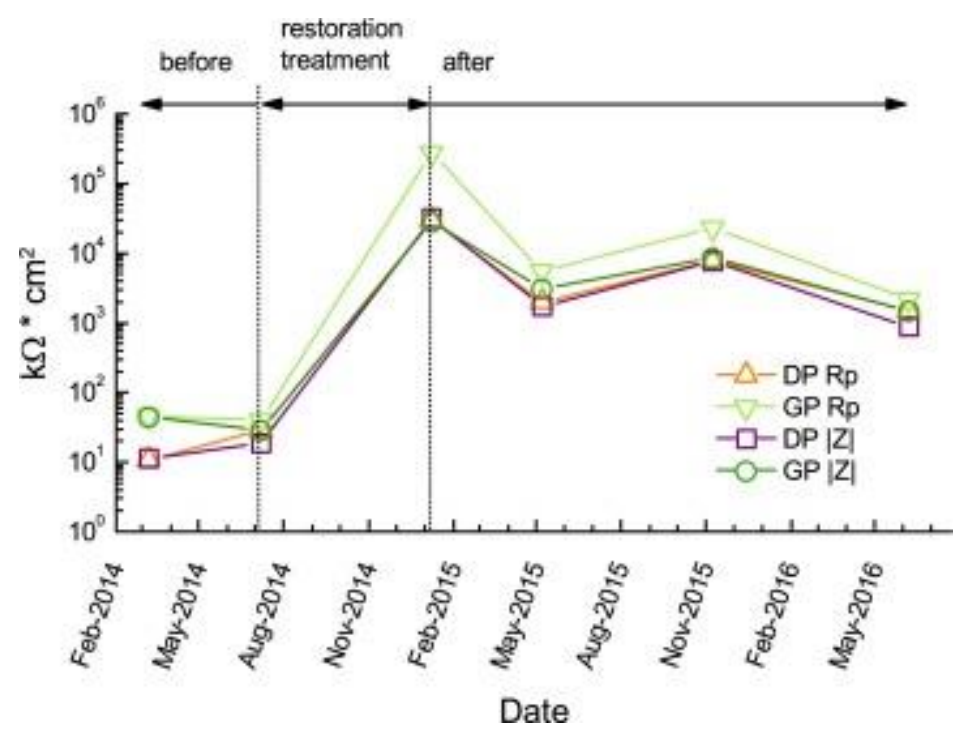

Fig. 5. |Z| limit and Rp before and after restoration treatments for dark patina (DP) and green patina (GP).

Overall, there is a good agreement between $\mathrm{Rp}$ and $|\mathrm{Z}|$ values, showing similar results and the same evolution with time, validating the approach of using $|Z|$ at low frequencies as measure of the corrosion resistance of the system. In the case of GP after the whole protection treatment, some discrepancy between these parameters seems to appear. This might be related with diffusion or other phenomena that are disregarded by the simplification of taking the values of $|Z|$ at low frequencies, or with inaccuracy of the estimation of this value in the noisy spectra. In any case, the evolution of both parameters shows the same pattern, leading to the same conclusions.

Although we have not enough experimental data for inferring a kinetic model for coating's resistance decay, we can try to obtain a rough estimate on the duration of our coating. Some attempts have been done to develop models or equations to predict service life for industrial coatings. Studies from Bierwagen et al. have found that the evolution of $|z|$ values in the low frequency portion of the spectrum that can be fit by a simple exponential decay function in time $[38,39]$. Fitting the values of $|Z|$ to a simple first order equation: $\operatorname{Ln}|\mathrm{Z}|=\operatorname{Ln}|\mathrm{Z}|_{0}-\mathrm{kt}$ (where 
$|Z|$ is the variation of $|Z|_{15.8 \mathrm{mHz}},|\mathrm{Z}|_{\text {。 }}$ the value before treatment in $\mathrm{kOhm}, \mathrm{k}$ is the rate constant and $t$ the time in months) and calculating the time for $|z|$ decay to its initial value, i.e. before restoration, the sphinx's coating will fail in about 4 years (figure 6 ).

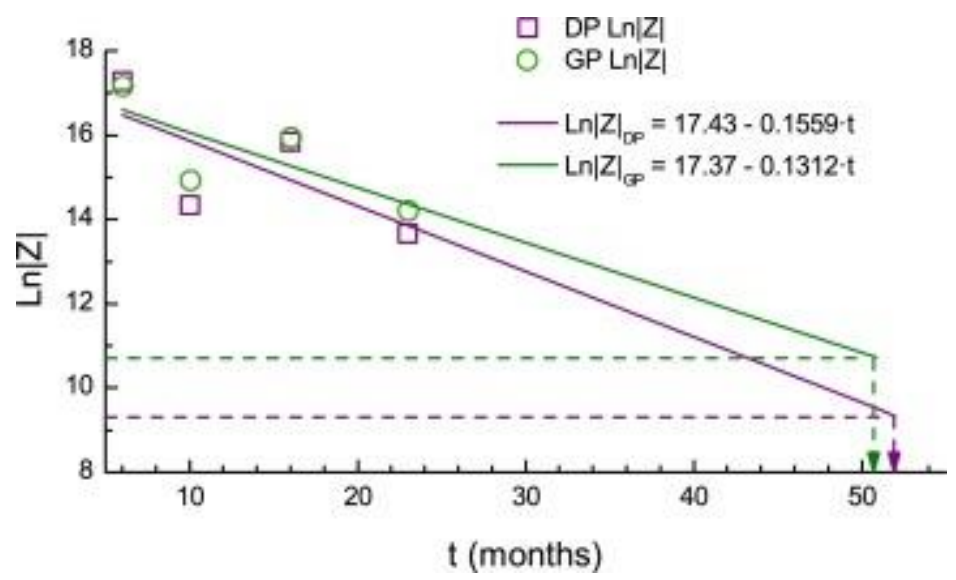

Fig. 6. Lifetime prediction of coatings from EIS data, based on a first order kinetic approach.

This result is in agreement with previously reported duration of this kind of coatings, as longterm protection coatings for cultural heritage are estimated for 5-10 year service [40]. According to Brostoff, Incralac coatings are expected to last 3-5 years in outdoor environments [41] while some authors report up to 9 years with topcoats of wax and regular maintenance [42]. It is clear that the duration of the coating depends on too many factors such as substrate characteristics, thickness, regularity, defects and environment, so a regular monitoring of the performance of the coating would be necessary for each individual artifact.

\section{Conclusions}

This study has validated the utility and applicability of the agar gel polymer electrolyte (G-PE) cell for protective treatments evaluation on outdoor bronze sculpture. It has proven to be convenient for field measurements and has allowed carrying out electrochemical measurements on different positions and orientations of the surface of the monument.

On-site EIS and Rp results obtained using the G-PE cell have demonstrated to be a useful tool for conservation treatments assessment. Experimental data have shown the effectiveness of the protection layers and allowed to follow its evolution. Assuming an exponential decay of coating resistance, a rough estimation of the coating's duration can be extrapolated to about 4 years.

The systematic application of the G-PE cell in future work to a wider collection of outdoor sculpture will allow refining the model and obtaining more accurate predictions. This will help to stablish a calendar for periodic inspections and design an efficient maintenance plan for these collections. 


\section{Acknowledgments}

This research has been funded by the Spanish Ministry of Economy (MINECO) with the research projects HAR2011-22402 and HAR2014-54893-R and FPI grants BES-2012-052716 and BES-2015-071472; and by Comunidad de Madrid and European Social Fund under Geomateriales 2 Programme (S2013/MIT_2914).

Authors want to acknowledge the Museo Arqueológico Nacional of Madrid, especially to Teresa Gómez Espinosa, for giving the opportunity of carrying out this research. Thanks are due too to Fernando Guerra-Librero, from Artyco, for detailed information on the conservation treatments on the sphinxes. 


\section{Bibliography}

[1] S. Díaz Martínez, Acciones de conservación y tratamiento de restauración aplicado a las esfinges del Museo Arqueológico Nacional de Madrid. Esculturas expuestas en atmósfera urbana, Boletín del Museo Arqueológico Nacional, 33 (2015) 267-283.

[2] E. Cano, D.M. Bastidas, V. Argyropoulos, S. Fajardo, A. Siatou, J.M. Bastidas, C. Degrigny, Electrochemical characterization of organic coatings for protection of historic steel artefacts, Journal of Solid State Electrochemistry, 14 (2010) 453-463.

[3] E. Cano, D. Lafuente, D.M. Bastidas, Use of EIS for the evaluation of the protective properties of coatings for metallic cultural heritage: A review, Journal of Solid State Electrochemistry, 14 (2010) 381-391.

[4] U. Rammelt, G. Reinhard, Application of electrochemical impedance spectroscopy (EIS) for characterizing the corrosion-protective performance of organic coatings on metals, Progress in Organic Coatings, 21 (1992) 205-226.

[5] P. Letardi, Laboratory and field tests on patinas and protective coating systems for outdoor bronze monuments, in: J. Ashton, D. Hallam (Eds.) Metal 04: Proceedings of the International Conference on Metals Conservation, National Museum of Australia, Canberra, Australia, 2004.

[6] P. Letardi, G. Luciano, Survey of EIS measurements on copper and bronze patinas, in: C. Degrigny, R. Van Lang, I. Joosten, B. Ankersmith (Eds.) Metal 07. Interim meeting of the ICOMCC Metal WG, Amsterdam (Netherland), 2007, pp. 44-50.

[7] C. Price, D. Hallam, G. Heath, D. Creagh, J. Ashton, An electrochemical study of waxes for bronze sculpture, in: I.D. MacLeod, S.L. Pennec, L. Robbiola (Eds.) Metal 95. International Conference on Metal Conservation James \& James, Semur-en-Auxois (France), 1995, pp. 233241.

[8] V. Otieno-Alego, D. Hallam, A. Viduka, G. Heath, D. Creagh, Electrochemical impedance studies of the corrosion resistance of wax coatings on artificially patinated bronze, in: J. Ashton, D. Hallam (Eds.) Metal 98. International Conference on Metal Conservation James \& James, Draguignan-Figanières (France), 1998, pp. 315-319

[9] G. Bierwagen, T.J. Shedlosky, K. Stanek, Developing and testing a new generation of protective coatings for outdoor bronze sculpture, Progress in Organic Coatings, 48 (2003) 289296.

[10] L.A.B. Ellingson, L.B.; Shedlosky, T. J.; Bierwagen, G. P.; De la Rie, E. René, The use of electrochemical impedance spectroscopy in the evaluation of coatings for outdoor bronze, Studies in Conservation, 49 (2004) 53-62.

[11] C.J. McNamara, M. Breuker, M. Helms, T.D. Perry, R. Mitchell, Biodeterioration of Incralac used for the protection of bronze monuments, Journal of Cultural Heritage, 5 (2004) 361-364.

[12] P. Letardi, A. Beccaria, M. Marabelli, G. D'Ercoli, Application of electrochemical impedance measurements as a tool for the characterization of the conservation and protection state of bronze works of art, in: J. Ashton, D. Hallam (Eds.) Metal 98. International Conference on Metal Conservation James \& James, Draguignan-Figanières (France), 1998, pp. 303-308.

[13] P. Letardi, R. Spiniello, Characterisation of bronze corrosion and protection by contactprobe electrochemical impedance measurements, in: I. MacLeod, J.M. Theile, C. Degrigny (Eds.) Metal 01. International Conference on Metal Conservation Western Australian Museum, Santiago (Chile), 2001, pp. 316-319.

[14] E. Angelini, A. Carullo, S. Corbellini, F. Ferraris, V. Gallone, S. Grassini, M. Parvis, A. Vallan, Handheld-impedance-measurement system with seven-decade capability and potentiostatic function, IEEE Transactions on Instrumentation and Measurement, 55 (2006) 436-441.

[15] E. Angelini, S. Grassini, S. Corbellini, G.M. Ingo, T. De Caro, P. Plescia, C. Riccucci, A. Bianco, S. Agostini, Potentialities of XRF and EIS portable instruments for the characterisation of ancient artefacts, Applied Physics A: Materials Science and Processing, 83 (2006) 643-649.

[16] E. Angelini, S. Grassini, M. Parvis, F. Zucchi, An in situ investigation of the corrosion behaviour of a weathering steel work of art, Surface and Interface Analysis, 44 (2012) 942-946.

[17] T.L. Clare, A. England, N. Swartz, K. Hosbein, Onsite electrochemical monitoring method for early detection of coating failure, in: V.G. Ewan Hyslop, Lore Troalen, Lyn Wilson (Ed.) METAL 2013, EDINBURGH, 2013.

[18] A.H. England, T.L. Clare, Synthesis and characterization of flexible hydrogel electrodes for electrochemical impedance measurements of protective coatings on metal sculptures, Electroanalysis, 26 (2014) 1059-1067. 
[19] E. Cano, A. Crespo, D. Lafuente, B. Ramírez Barat, A novel gel polymer electrolyte cell for in-situ application of corrosion electrochemical techniques, Electrochemistry Communications, 41 (2014) 16-19.

[20] B. Ramírez Barat, E. Cano, The use of agar gelled electrolyte for in situ electrochemical measurements on metallic cultural heritage, Electrochimica Acta, 182 (2015) 751-762.

[21] B. Ramírez Barat, E. Cano, Evaluación in situ de recubrimientos protectores para patrimonio cultural metálico mediante espectroscopía de impedancia electroquímica, Geconservación, 8 (2015) 6-13.

[22] S.N. Inamdar, M.A. Bhat, S.K. Haram, Construction of Ag/AgCl Reference Electrode from Used Felt-Tipped Pen Barrel for Undergraduate Laboratory, Journal of Chemical Education, 86 (2009) 355-356.

[23] E. Bernardi, C. Chiavari, B. Lenza, C. Martini, L. Morselli, F. Ospitali, L. Robbiola, The atmospheric corrosion of quaternary bronzes: The leaching action of acid rain, Corrosion Science, 51 (2009) 159-170.

[24] P. Letardi, Electrochemical measurements in the conservation of metallic heritage artefacts: An overview, in: Corrosion and Conservation of Cultural Heritage Metallic Artefacts, 2013, pp. 126-148.

[25] A. Crespo, B. Ramírez Barat, D. Lafuente, S. Diaz, E. García, E. Cano, Non-destructive electrochemical evaluation of the patinas on the bronze sphinxes of the Museo Arqueológico Nacional in Madrid, in: Art'14. 11 th International Conference on non-destructive investigations and microanalysis for the diagnostics and conservation of cultural and environmental heritage., Madrid, 2014.

[26] N. Swartz, T.L. Clare, On the protective nature of wax coatings for culturally significant outdoor metalworks: Microstructural flaws, oxidative changes, and barrier properties, Journal of the American Institute for Conservation, 54 (2015) 181-201.

[27] L. Beaunier, I. Epelboin, J.C. Lestrade, H. Takenouti, Etude electrochimique, et par microscopie electronique a balayage, du fer recouvert de peinture, Surface Technology, 4 (1976) 237-254.

[28] A. Doménech-Carbó, M. Lastras, F. Rodríguez, E. Cano, J. Piquero-Cilla, L. Osete-Cortina, Monitoring stabilizing procedures of archaeological iron using electrochemical impedance spectroscopy, Journal of Solid State Electrochemistry, 18 (2014) 399-409.

[29] B. Hirschorn, M.E. Orazem, B. Tribollet, V. Vivier, I. Frateur, M. Musiani, Determination of effective capacitance and film thickness from constant-phase-element parameters, Electrochimica Acta, 55 (2010) 6218-6227.

[30] R.D.P.B. Hernández, I.V. Aoki, B. Tribollet, H.G. De Melo, Electrochemical impedance spectroscopy investigation of the electrochemical behaviour of copper coated with artificial patina layers and submitted to wet and dry cycles, Electrochimica Acta, 56 (2011) 2801-2814.

[31] D.M. Bastidas, Interpretation of impedance data for porous electrodes and diffusion processes, Corrosion, 63 (2007) 515-521.

[32] F. Mansfeld, Use of electrochemical impedance spectroscopy for the study of corrosion protection by polymer coatings, Journal of Applied Electrochemistry, 25 (1995) 187-202.

[33] M. Kendig, J. Scully, Basic Aspects of Electrochemical Impedance Application for the Life Prediction of Organic Coatings on Metals, Corrosion, 46 (1990) 22-29.

[34] J.N. Murray, Electrochemical test methods for evaluating organic coatings on metals: An update. Part III: Multiple test parameter measurements, Progress in Organic Coatings, 31 (1997) 375-391.

[35] G. Bierwagen, T.J. Shedlosky, L.A. Ellingson, Electrochemical studies of the protection of bronzes from corrosion by organic coatings, in: I. MacLeod, J.M. Theile, C. Degrigny (Eds.) Metal 01. International Conference on Metal Conservation Western Australian Museum, Santiago (Chile), 2001, pp. 291-296.

[36] T.L. Clare, P.A. Lins, Evaluation of fluorinated protective coatings for outdoor metals, in: C. Degrigny, R. Van Lang, I. Joosten, B. Ankersmith (Eds.) Metal 07. Interim meeting of the ICOMCC Metal WG, Rijksmuseum Amsterdam, Amsterdam (The Neatherlands), 2007, pp. 8387.

[37] E. Joseph, P. Letardi, R. Mazzeo, S. Prati, M. Vandini, Innovative treatments for the protection of outdoor bronze monuments, in: C. Degrigny, R. Van Lang, I. Joosten, B. Ankersmith (Eds.) Metal 07. Interim meeting of the ICOM-CC Metal WG, Rijksmuseum Amsterdam, Amsterdam (The Neatherlands), 2007, pp. 71-77. 
[38] G. Bierwagen, J. Li, L. He, D. Tallman, Fundamentals of the Measurement of Corrosion Protection and the Prediction of Its Lifetime in Organic Coatings, in: Service Life Prediction, American Chemical Society, 2001, pp. 316-350.

[39] B.R. Hinderliter, S.G. Croll, D.E. Tallman, Q. Su, G. Bierwagen, Interpretation of EIS data from accelerated exposure of coated metals based on modeling of coating physical properties, Electrochimica Acta, 51 (2006) 4505-4515.

[40] C. Degrigny, The search for new and safe materials for protecting metal objects, in: V. Argyropoulos (Ed.) Metals and Museums in the Mediterranean. Protecting, Preserving and Interpreting, TEl of Athens-PROMET project, Athens, 2008, pp. 179-235.

[41] L.B. Brostoff, Coating strategies for the protection of outdoor bronze art and ornamentation, in: Faculteit der Natuurwetenschappen, Wiskunde en Informatica, Amsterdam, 2003.

[42] C. Craine, K. Severson, S. Merritt, Prospects for the Long Term Maintenance of Outdoor Bronze Sculpture: The Shaw Memorial Nine Years After Cleaning and Coating,, in: AIC 2th Annual Meeting, Buffalo, New York, 1992. 